\title{
Jejak Sukses Gerakan Kewirausahaan Sosial
}

\author{
Habsul Nurhadi \\ Institut Ilmu Sosial dan Manajemen STIAMI \\ tophabsul@gmail.com
}

\section{ARTICLE INFO}

ABSTRACT

Keywords:

The social entrepreneurship movement in Indonesia, although generally equally aims to help improve the "comfort" of local life, but it turns out the form of activity is very

Social Entrepreneurshi,

Local life,

Economic Empowerment diverse, depending on the availability of the superior carrying capacity that is in the local community. The social entrepreneurship movement in Indonesia is moving through the field of economic empowerment, through the field of family welfare, through the field of formal education of children, through the field of non-formal education, through the field of health, through the field of environmental sustainability, through the field of environmental hygiene / health; there are still many other fields of work.

This study attempts to find information and analyze the typology-related mapping of the phenomenon of the social entrepreneurship movement that occurred in Indonesia. This study is still a preliminary study, as further studies are needed, such as to reveal what factors are driving the spirit of social entrepreneurship in society, what factors trigger unyielding spirit in solving the response community issues, and other useful and inspiring information.

\section{PENDAHULUAN}

Indonesia memiliki potensi ekonomi yang sangat besar. Jumlah penduduk Indonesia menduduki peringkat empat besar dunia, setelah China (1,37 milyar jiwa atau 18,8 persen penduduk dunia), India (1,26 milyar jiwa atau 17,3 persen), dan Amerika Serikat (323 juta jiwa atau 4,4 persen), maka Indonesia berdasarkan data CIA World Factbook Tahun 2016 memiliki jumlah penduduk 258 juta jiwa (tepatnya 258.316.051 jiwa) atau 3,5 persen dari jumlah penduduk dunia.

Selain itu, Indonesia yang memiliki wilayah daratan dan lautan seluas total 5,1 juta km2 (tepatnya 5.193.250 km2 termasuk luas daratannya $1.919 .440 \mathrm{~km} 2$ ), ternyata merupakan luas wilayah terbesar ketujuh di dunia, setelah Rusia (17,0 juta km2), China (14,5 juta km2), Kanada (9,9 juta km2), Amerika Serikat (9,6 juta km2), Brazil (8,5 juta km2), dan Australia (7,6 juta km2).

Belum lagi sumber daya alam Indonesia yang sangat kaya raya, dimana segala sesuatu yang berasal dari alam Indonesia nyaris semuanya dapat digunakan untuk memenuhi kebutuhan hidup manusia, baik kekayaan alam aneka hayati, berbagai hasil hutan dan perkebunan, berbagai biota laut, maupun berbagai jenis bahan tambang, seperti minyak bumi, gas alam, timah, nikel, tembaga, bauksit, batubara, emas, perak. Artinya, potensi Indonesia boleh dikatakan sangat luar biasa besarnya.

Menurut catatan mantan Wakil Menteri Perdagangan, Bayu Krisnamurthi, kehidupan perekonomian Indonesia pada tahun 2015 lalu menempati urutan ke-16 terbesar ekonomi dunia, dan pada tahun 2030 mendatang berpotensi akan meningkat menjadi ekonomi terbesar ketujuh di dunia. (lihat Sakina Rakhma Diah Setiawan)

Namun sayangnya, perekonomian di Indonesia selama ini masih menghadapi ketimpangan yang sangat besar, dimana 1 persen orang terkaya di Indonesia menguasai sekitar 49 persen perekonomian nasional.

Selain itu, Indonesia juga masih menghadapi kemiskinan dan berbagai masalah sosial. Menurut data Badan Pusat Statistik, angka pengangguran dan kemiskinan di Indonesia masih sangat tinggi, dimana jumlah pengangguran pada tahun 2012 mencapai 7,6 juta orang, dan jumlah penduduk miskin di Indonesia pada Maret 2012 mencapai 29,13 juta orang, atau 11,96 persen dari jumlah penduduk. (lihat Luthfi Destianto)

Keadaan melimpahnya potensi kekayaan alam Indonesia, namun dibarengi dengan fakta masih banyaknya warga masyarakat yang miskin ekonomi dan rendah pendidikan tersebut, sungguh merupakan suatu ironi. Sehingga oleh karenanya, sebagai salah satu solusi penanggulangannya, adalah dengan cara 
mengembangkan semangat kewirausahaan sosial secara merata di berbagai wilayah, yang dapat dilakukan oleh semua kalangan, apalagi didukung adanya kecenderungan masyarakat Indonesia yang memiliki semangat kewirausahaan yang tinggi. Diharapkan, dengan semakin meratanya gerakan dan semangat kewirausahaan sosial, maka potensi sumber daya manusia Indonesia pada gilirannya akan dapat semakin meningkat kualitasnya.

Kajian ini dimaksudkan untuk mencari informasi dan menganalisis mengenai tipologi gerakan kewirausahaan sosial di Indonesia. Hasil yang diharapkan dari kajian ini adalah didapatkannya gambaran (pemetaan) tipologi gerakan kewirausahaan sosial yang secara umum terjadi di Indonesia.

Manfaat secara umum dari kajian ini adalah diperolehnya beberapa informasi awal yang diharapkan dapat dijadikan sebagai bahan formula "virus" positif, yang pada giliran selanjutnya dapat dikembangkan untuk ditularkan dan diimplementasikan pada daerah-daerah lain, guna membantu menanggulangi adanya permasalahan yang terjadi di tengah masyarakatnya.

\section{KERANGKA TEORI}

Kewirausahaan sosial atau Social Entrepreneurship merupakan sebuah istilah turunan dari kewirausahaan. Kewirausahaan sosial adalah aktivitas yang menggabungkan pendekatan bisnis dan kesejahteraan sosial. Kewirausahaan sosial, menurut Vasudha Vasakaria (2008) yang dikutip dalam Wikipedia, adalah disiplin ilmu yang menggabungkan antara kecerdasan berbisnis, inovasi, dan tekad untuk maju ke depan. (lihat Wikipedia, Kewirausahaan Sosial)

Sesungguhnya gerakan kewirausahaan sosial atau social entrepreneurship sudah dikenal di dunia ratusan tahun yang lalu, diawali antara lain oleh Florence Nightingale, yang merupakan pelopor pertama pendiri sekolah perawat. Florence Nightingale (1820-1910), seorang wanita berkebangsaan Inggris, yang dilahirkan di Firenze (Italia) pada 12 Mei 1820 dan meninggal di London (Inggris) pada 13 Agustus 1910, adalah seorang pelopor perawat modern, yang terkenal dengan julukan "The Lady with The Lamp" (Bidadari Berlampu), atas jasanya yang tanpa kenal rasa takut mengumpulkan dan merawat korban perang pada Perang Krimea, di Semenanjung Krimea, Rusia.

Juga Robert Owen, yang merupakan pelopor pendiri badan usaha koperasi. Robert Owen, yang dilahirkan di Newton (Wales, Britania Raya) pada 14 Mei 1771 dan meninggal di Newton (Wales, Britania Raya) pada 17 November 1858 dalam usia 87 tahun, adalah seorang pemikir utama sosialisme utopis, dan sekaligus seorang pelaku bisnis sukses yang menyumbangkan banyak laba usahanya demi peningkatan taraf hidup para karyawannya. Robert Owen dianggap sebagai "Bapak Gerakan Koperasi" di dunia.

Kemudian, sejak tahun 1980 lalu, istilah social entrepreneurship kembali marak mencuat ke permukaan pemberitaan pers, setelah beberapa tokoh seperti Rosabeth Moss Kanter, Bill Drayton, Charles Leadbeater, menyumbangkan kiprah karya profesinya. Rosabeth Moss Kanter, seorang wanita berkebangsaan Amerika Serikat, kelahiran Cleveland, Ohio, Amerika Serikat, pada 15 Maret 1943. Ia terkenal sebagai seorang pakar Ilmu Sosial, yang pemikiran-pemikiran briliannya banyak dituangkan dalam beberapa buku karyanya, antara lain "Commitment and Community" (1972),

"Men and Women of the Corporation" (1977), "The Change Masters" (1983), "When Giants Learn to Dance" (1989), dan "Supercorp : How Vanguard Companies Create Innovation, Profits, Growth, and Social Good" (2009).

Sedangkan Bill Drayton, kelahiran New York (Amerika Serikat) pada tahun 1943, yang kemudian pada tahun 1980 mendirikan organisasi "Ashoka: Innovators for The Public", merupakan seorang pelopor gerakan wirausaha sosial di dunia. Organisasi Ashoka ini mempunyai cita-cita, agar setiap orang di dunia ini bersemangat untuk menjadi pembaharu, sehingga missi Ashoka adalah

memperkuat sektor masyarakat sipil melalui pendekatan kewirausahaan sosial. Ashoka meyakini bahwa sektor sosial yang produktif, berjiwa, dan berdaya saing, akan mampu menciptakan lingkungan dimana setiap orang akan mampu menjadi pembawa perubahan. Ashoka berhasil membentuk 60 organisasi pendorong upaya kewirausaan sosial yang tersebar di seluruh dunia. Mereka mencoba melayani pasar yang belum digarap, menghilangkan kesenjangan dalam kesejahteraan, pendidikan, kesehatan, demografis, dan peluang bekerja bagi masyarakat.

Sementara Charles Leadbeater, adalah seorang penulis pria berkebangsaan Inggris yang lahir pada tahun 1959. Ia pernah menjadi penasehat Perdana Menteri Inggris Tony Blair. Buku-buku karyanya yang terkenal antara lain "The Rise of the Social Entrepreneur", dan "Personalisation Through Participation" (2004). 
Konsep secara umum dari kewirausahaan sosial sebenarnya bukan berarti sebuah lembaga atau organisasi bentukan atau turunan dari perusahaan swasta, misalnya melalui program Corporate Social Responsibility, maupun bukan dari lembaga pemerintahan, misalnya dari Dinas Sosial, akan tetapi murni merupakan sebuah usaha kewirausahaan yang bergerak di bidang sosial. Pada awalnya, kewirausahaan sosial mempunyai inti pemberdayaan dalam bidang kemasyarakatan yang bersifat voluntary (sukarela) dan charity (kedermawanan), seperti lembaga-lembaga sosial panti asuhan, program orangtua anak asuh, donasi beasiswa pendidikan, dan sebagainya, yang tidak menekankan pada motif mencari profit, melainkan lebih mengutamakan pada pemberdayaan masyarakat untuk kemaslahatan bersama. (lihat Nur Rahman Arif)

Sedangkan menurut Monaliasakwati, kewirausahaan sosial merupakan solusi alternatif yang kreatif, karena tidak hanya berorientasi pada keuntungan belaka, akan tetapi juga kesejahteraan masyarakat, dimana masyarakat akan terlibat langsung menjadi pelaku bisnis, dan kentungannya akan dikembalikan lagi ke masyarakat untuk dikembangkan secara berkelanjutan. Kewirausahaan sosial mempunyai tujuan jangka panjang untuk membantu masyarakat menjadi lebih mandiri dalam segi finansial dan tidak menggantungkan pada kebijakan pemerintah seperti subsidi dan bantuan langsung tunai. (lihat Monaliasakwati)

Kewirausahaan sosial menitik-beratkan usahanya sejak awal dengan melibatkan dan memberdayakan masyarakat yang kurang mampu secara finansial maupun keterampilan untuk secara bersama-sama menggerakkan usahanya agar menghasilkan keuntungan, dan kemudian hasil usaha atau keuntungannya dikembalikan kembali ke masyarakat untuk meningkatkan pendapatannya. Melalui metode tersebut, menurut Luthfi Destianto, kewirausahaan sosial bukan hanya mampu menciptakan banyak lapangan kerja, tetapi juga menciptakan multiplier effect untuk menggerakkan roda perekonomian dan menciptakan kesejahteraan sosial. Lebih lanjut, menurut Direktur Dompet Dhuafa, Rini Suprihartanti, kewirausahaan sosial diyakini dapat dijadikan sebagai modal mengentaskan kemiskinan untuk tujuan pembangunan berkelanjutan.

Sedangkan pengertian Wirausaha Sosial, atau ada pula yang menyebutnya Wirausahawan Sosial, menurut Karen Braun (2009) yang dikutip dalam Wikipedia, adalah seseorang atau sekelompok orang yang melihat masalah yang terjadi dalam masyarakat sebagai peluang untuk membentuk model bisnis baru yang bermanfaat bagi pemberdayaan masyarakat sekitar. Mereka berupaya secara berkelanjutan melalui ide-ide yang berbeda untuk mengatasi masalah-masalah sosial yang signifikan.

Andrew C.T. Thompson (dalam Isa Wahyudi dan Busyra Azheri, 2008) mendefinisikan wirausaha sosial sebagai orang-orang yang dengan sikap pengusaha bisnis tetapi beroperasi di

masyarakat. Mereka bertindak lebih sebagai pengasuh dari masyarakat, dan bukan sebagai pengusaha yang dengan mudah menghasilkan uang. Wirausaha sosial harus memiliki misi sosial, yang semata-mata hanya untuk membuat masyarakat dapat terbebaskan dari permasalahan yang terjadi. (lihat Wikipedia, Kewirausahaan Sosial)

Ashoka Indonesia mendefinisikan Wirausahawan Sosial sebagai individu yang memiliki solusi inovatif untuk menyelesaikan permasalahan sosial di masyarakat. Mereka sangat ambisius dan pantang menyerah untuk menangani masalah sosial yang besar serta menawarkan ide-ide baru untuk membawa perubahan yang lebih luas.

Wirausahawan sosial berfokus pada kondisi dimana sektor sosial yang seharusnya berjalan belum bekerja dengan baik, dan memecahkan permasalahan tersebut dengan cara mengubah sistem, menawarkan solusi, dan mengajak masyarakat untuk melakukan lompatan baru dalam menghadapi permasalahan mereka. Dengan kata lain, wirausahawan sosial adalah orang yang melibatkan komunitas masyarakat setempat untuk terlibat dan melakukan perubahan bagi kehidupan mereka.

Menurut Bill Drayton, tugas wirausahawan sosial adalah mengenali adanya kemacetan atau kemandegan dalam kehidupan masyarakat, dan menyediakan jalan keluar dari kemacetan dan kemandegan itu, dengan cara menemukan apa yang tidak berfungsi, memecahkan masalah dengan mengubah sistemnya, menyebarluaskan pemecahannya, dan meyakinkan seluruh warga masyarakat untuk berani melakukan perubahan.

Wirausahawan sosial selalu memiliki ide-ide baru, dan mendedikasikan kehidupan mereka untuk melakukan perubahan pada kondisi sosial mereka. Mereka memiliki pandangan yang jauh ke depan, dengan tujuan akhir yang jelas, berfokus pada implementasi praktis untuk mewujudkan visi mereka.

\section{METODE}

Metode yang digunakan dalam kajian ini adalah metode studi kepustakaan (library research), yakni teknik pengumpulan data dengan mengadakan studi penelaahan terhadap buku-buku, literatur-literatur, 
catatan-catatan, dan laporan-laporan yang ada hubungannya dengan masalah yang dipecahkan. (lihat Nazir, 2003)

Lebih lanjut dikatakan, bahwa studi kepustakaan merupakan langkah yang penting dimana setelah seorang peneliti menetapkan topik penelitian, langkah selanjutnya adalah melakukan kajian yang berkaitan dengan topik penelitian. Dalam pencarian teori, peneliti akan mengumpulkan informasi sebanyak-banyaknya dari kepustakaan, yang dapat diperoleh dari buku, jurnal, majalah, hasil-hasil penelitian, dan sumber-sumber lainnya yang sesuai, termasuk misalnya dari internet, koran, dan lain-lain. (lihat Nazir, 2003)

Ada empat ciri utama dari studi kepustakaan. Pertama, peneliti berhadapan langsung dengan teks (nash) atau data angka, dan bukan dengan pengetahuan langsung dari lapangan atau saksi mata (eye witness) berupa kejadian, orang, maupun benda lainnya. Teks memiliki sifat-sifatnya sendiri dan memerlukan pendekatan tersendiri, dimana teknik membaca teks (buku, artikel, dokumen) menjadi bagian yang fundamental dalam penelitian kepustakaan.

Kedua, data pustaka bersifat siap pakai, dimana peneliti tidak perlu pergi ke mana-mana lagi, selain hanya berhadapan langsung dengan bahan sumber yang sudah tersedia di perpustakaan. Ketiga, data perpustakaan umumnya berupa sumber data sekunder, sehingga peneliti memperoleh bahan informasinya adalah dari tangan kedua dan bukannya data orisinil dari tangan pertama di lapangan. Keempat, kondisi data pustaka tidak dibatasi oleh ruang dan waktu, sehingga peneliti seakan berhadapan dengan informasi statis dan mati, karena datanya akan selalu tetap dan tidak akan pernah berubah. (lihat Mestika zed, 2008)

\section{PEMBAHASAN}

Secara umum ada beberapa peran yang dapat diemban oleh gerakan kewirausahaan sosial, diantaranya adalah :

1. Gerakan kewirausahaan sosial mampu menciptakan kesempatan kerja yang baru, juga memberikan peluang kerja bagi para penyandang cacat dan penyandang disabilitas lainnya untuk ikut dilibatkan dalam berbagai kegiatan produktif.

2. Gerakan kewirausahaan sosial mampu mendorong munculnya inovasi dan kreasi gerakan masyarakat, terutama pada persoalan-persoalan yang belum secara tuntas tertangani oleh pihak pemerintah, seperti misalnya gerakan pengentasan penderita HIV dan korban narkoba, gerakan pemberantasan buta huruf, gerakan penanggulangan masyarakat kurang gizi, serta lainnya.

3. Gerakan kewirausahaan sosial mampu dijadikan sebagai suatu modal sosial yang penting dalam berbagai bentuk kemitraan ekonomi dalam upaya pengentasan kemiskinan masyarakat. Modal sosial itu mencakup nilai-nilai saling pengertian, kepercayaan, serta budaya kerjasama, yang sangat berguna dalam membangun dan meningkatkan jaringan kepercayaan dan kerjasama, yang selanjutnya dapat mengakses pembangunan fisik, aspek keuangan, maupun optimalisasi

4. pemberdayaan sumber daya manusia, sehingga diharapkan dapat semakin banyak terbangun berbagai sarana sosial yang diperlukan.

5. Gerakan kewirausahaan sosial diharapkan mampu mewujudkan adanya kesetaraan dan pemerataan kesejahteraan masyarakat, guna lebih memungkinkan terselenggaranya pembangunan ekonomi yang berkelanjutan.

Selanjutnya akan dikemukakan beberapa contoh kisah sukses gerakan kewirausahaan sosial. Gerakan kewirausahaan sosial yang disebutkan pada uraian berikut ini masih sangat terbatas jumlahnya, yakni masih sebatas berasal dari pemberitaan media massa, sehingga diyakini sesungguhnya masih banyak aneka ragam gerakan-gerakan kewirausahaan sosial lainnya yang telah berhasil menanggulangi permasalahanpermasalahan yang terjadi pada masyarakatnya.

Tingkat Internasional :

1. Dr. Maria Montessori (lahir di Italia pada 31 Agustus 1870, dan meninggal di Belanda pada 6 Mei 1952), adalah seorang pendidik, ilmuwan, dan dokter berkebangsaan Italia. Ia mengembangkan sebuah metode pendidikan anak-anak dengan memberi kebebasan bagi anak-anak untuk melakukan kegiatan dan mengatur acara harian. Metode pendidikan Montessori tersebut kemudian berkembang dan menyebar ke seluruh dunia.

2. John Muir (Amerika Serikat), adalah seorang filosof yang sangat peduli pada kelestarian lingkungan alam, seorang pelopor pembuat lembaga perlindungan konservasi kebun binatang, serta pendiri lembaga Sierra Club di San Francisco pada 28 Mei 1892, yakni organisasi yang bergerak dalam kelestrian lingkungan hidup. Beberapa buku karyanya, antara lain "The Mountains of California" 
(1875), "My First Summer in The Sierra" (1911), "The Yosemite" (1912), "Travels in Alaska" (1915). Ia meninggal di California (Amerika Serikat) pada 24 Desember 1914.

3. Bill Drayton yang pada tahun 1980 mendirikan Ashoka Fellows, organisasi yang mencari dan membantu para wirausahawan sosial, serta menyeponsori lebih dari 2000 fellow di lebih dari 70 negara di dunia. Bill Drayton adalah orang yang giat mempromosikan kewirausahaan sosial ke seluruh penjuru dunia.

4. Dr. Muhammad Yunus, pendiri Grameen Bank di Bangladesh, yang menyediakan kredit mikro bagi masyarakat kelas bawah, yang terbukti hampir semua (98 persen) masyarakat kelas bawah dapat melunasi hutang-hutangnya. Beberapa buku karyanya, antara lain "Banker to The Poor" (1999), "Creating a World Without Poverty" (2007), "Building Social Business" (2010), "A World Three Zeros : The New Economics of Zero Poverty, Zero Unemployment, and Zero Net Carbon Emissions" (2017). Muhammad Yunus pernah meraih penghargaan Nobel Perdamaian Dunia.

5. Blake Mycoskie, pendiri perusahaan sepatu merek Toms, yang akan mendonasikan sepasang sepatu kepada mereka yang membutuhkan dari setiap sepasang sepatu yang terjual.

6. Warren Buffet, yang lewat perusahaan investasinya ia menyumbangkan 99 persen dari seluruh profit usahanya kepada pihak lain, melalui bendera Bill Foundation. Ia hanya mengambil 1 persen keuntungan perusahaannya untuk kebutuhan keluarganya, karena ia tak menginginkan anak-anaknya merasa tak harus bekerja keras lantaran ayahnya memiliki banyak uang, sehingga ia menginginkan anak-anaknya tetap harus bekerja lebih banyak lagi bagi masyarakat.

Tingkat Nasional :

1. Dompet Dhuafa, yang pertama kali digagas oleh para jurnalis Republika, adalah lembaga nirlaba milik masyarakat Indonesia yang berkhidmat mengangkat harkat sosial kemanusiaan kaum dhuafa dengan dana Zakat, Infaq, Shadaqah, Wakaf, serta dana lainnya yang halal dan legal, dari perorangan, kelompok, perusahaan atau lembaga.

2. Rumah Zakat mengajak masyarakat untuk semakin banyak berbagi sebagai salah satu aksi nyata, guna membantu sesama ummat yang membutuhkan, dengan jumlah sasaran yang semakin banyak dan jangkauan wilayah garap yang semakin luas, dalam rangka menyebarkan kebahagiaan melalui perbaikan kondisi sosial kemasyarakatan. Program pemberdayaan masyarakatnya direalisasikan melalui empat rumpun utama, yaitu rumpun Senyum Juara (bidang pendidikan), rumpun Senyum Sehat (bidang kesehatan), rumpun Senyum Mandiri (bidang pemberdayaan ekonomi), dan rumpun Senyum Lestari (bidang kelestarian lingkungan).

3. Rumah Singgah merupakan sebuah wahana yang dipersiapkan sebagai perantara bagi anak jalanan dan orang-orang yang akan membantu mereka. Rumah singgah berfungsi sebagai tempat untuk tinggal sementara, maupun pusat kegiatan, serta pusat informasi bagi anak jalanan, yang dapat dimanfaatkan oleh para anak jalanan guna memperoleh hidup yang lebih baik.

4. Bank Sampah, adalah suatu tempat yang digunakan untuk mengumpulkan sampah yang sudah dipilahpilah, untuk kemudian disetorkan ke tempat pembuatan kerajinan atau ke tempat pengepul sampah. Bank sampah dikelola menggunakan sistem seperti perbankan yang dilakukan oleh petugas sukarelawan, dimana warga yang tinggal di sekitar lokasi bank akan mendapat buku tabungan seperti menabung di bank.

5. British Council, yang sejak tahun 2009 telah menyediakan pelatihan keterampilan dan pendampingan profesional guna mendukung lembaga-lembaga yang bergerak dalam bidang wirausaha sosial, dengan menggunakan pendekatan bisnis untuk memenuhi kebutuhan sosial dan lingkungan, sehingga mampu memberikan dampak positif bagi komunitas masyarakat binaannya. Kegiatan-kegiatan yang telah dilaksanakannya antara lain (1) Transformasi LSM Menjadi Kewirausahaan Sosial, guna mendukung organisasi nirlaba di Indonesia untuk mengubah program kegiatannya dengan pendekatan kewirausahaan sosial, (2) Kompetisi kewirausahaan sosial berbasis komunitas yang telah digelar British Council bekerjasama dengan Arthur Guinness Fund, (3) Kompetisi jurnalisme berbasis komunitas guna meningkatkan kesadaran masyarakat dalam membangun inisiatif masyarakat maupun memberitakan hasil-hasil kegiatan kewirausahaan sosial.

6. Bambang Ismawan, yang pada tahun 1967 bersama-sama Ir. Sayogyo dan Ir. Suradiman mendirikan Yayasan Sosial Tani Membangun, guna memberdayakan masyarakat miskin melalui kegiatan keuangan mikro dan usaha mikro, dengan mengutamakan kegiatan pendidikan anggota, memupuk kemampuan diri, dan kemampuan sosial. Yayasan Sosial Tani Membangun itu kemudian berubah menjadi Yayasan Bina Swadaya, sebuah lembaga kewirausahaan sosial yang terus berupaya 
menggerakkan kewirausahaan sosial masyakarat, antara lain melalui ajang pemberian apresiasi penghargaan Kusala Swadaya bagi tokoh pejuang kewirausahaan sosial dari kalangan masyarakat.

7. Hafiza Elvira Novitariani, pendiri Nalacity Foundation di Desa Sitanala, Tangerang, berhasil mempelopori gerakan berbasis komunitas yang memberdayakan masyarakat marjinal

8. penyandang difabel, terutama ibu-ibu mantan penderita penyakit kusta, untuk bisa menghasilkan kerajinan tangan berupa "jilbab", yang produknya kemudian dijual di Jakarta, dan keuntungan yang diperolehnya dikembalikan untuk meningkatkan pendapatan masyarakat agar kehidupan mereka dapat mandiri dan meningkat lebih baik. Kini Nalacity Foundation dipimpin oleh Yovita Salysa Aulia.

9. Fajri Mulya Iresha, pendiri CV Zero Waste Indonesia, telah berhasil membina dan memberdayakan kaum marjinal dan para pemulung dalam pengumpulan sampah di Depok, Jawa Barat. Fajri juga mengedukasi masyarakat tentang perbedaan sampah organik dan sampah non organik, serta pentingnya bank sampah.

10. Ahmad Tessario dari Banyuwangi, bergerak di sektor pertanian dengan mengembangkan beras organik, baik terdiri beras merah organik, beras putih organik, beras coklat organik, beras merah putih organik, serta beras hitam organik. Para petani yang bekerjasama dengan Ahmad Tessario selain mendapatkan peningkatan keuntungan dari hasil jual panen yang lebih tinggi, juga mendapatkan ilmu pengetahuan dan peningkatan produktivitas lahan seiring dengan digunakannya pupuk organik.

11. Ni Kadek Citra Ekawati dari Bali, yang memproduksi produk lulur Bali Alus dengan bahan-bahan tradisional guna perawatan tubuh. Sejak produksinya dimulai tahun 2000, Bali Alus telah mampu membantu peningkatan ekonomi kurang lebih 100 warga masyarakat sekitar, terutama kaum ibu-ibu rumah tangga yang dilibatkan dalam proses produksinya.

12. Putu Gede Asnawa Dikta dari Bali, yang sejak tahun 2012 telah berhasil mengembangkan Desa Sibetan di Bali menjadi Desa Wisata Agro Park Salak, serta mampu meningkatkan taraf perekonomian masyarakat sekitar melalui pengembangan aneka produk kreatif salak, dengan bahan baku buah salak maupun limbah salak.

13. Yayah Muslimah dari Purbalingga, Jawa Tengah, yang telah berhasil menciptakan lapangan kerja di Desa Kedungwuluh, Kecamatan Kalimanah, Kabupaten Purbalingga, melalui pendirian perusahaan "Yayah Eyelases", yang memproduksi bulu mata palsu.

14. Rhenald Kasali, pendiri Yayasan Rumah Perubahan, yang bertujuan untuk menjadikan Indonesia lebih baik melalui misi perubahan.

15. Tri Mumpuni, Direktur Lembaga Swadaya Masyarakat (LSM) Institut Bisnis dan Ekonomi Kerakyatan (IBEKA), yang sejak tahun 1992 bersama sang suami, berhasil membangun Pembangkit Listrik Tenaga Mikrohidro (PLTMH) sebagai sumber energi listrik bagi wilayah yang belum terjangkau atau sulit dijangkau oleh PT PLN, sehingga mampu mengembangkan kesejahteraan warga masyarakat melalui upaya peningkatan pemanfaatan tenaga listrik secara produktif.

16. Masril Koto, pendiri Lembaga Keuangan Mikro Agribisnis (LKMA) Prima Tani di Nagari Koto Tinggi, Kecamatan Baso, Kabupaten Agam, Sumatera Barat. Sejak tahun 2007 Masril berhasil menjadikan LKMA Prima Tani menjadi cikal bakal dari program Pengembangan Usaha Agribisnis Perdesaan (PUAP) secara nasional, yang diresmikan oleh Menteri Pertanian kala itu, Anton Apriyantono.

17. Silverius Oscar Unggul, Presiden Direktur Radio Swara Alam dan Televisi Kendari, berhasil memberdayakan masyarakat dalam pelestarian alam, terutama dalam memberikan perlawanan untuk mengusir para pembalak liar di hutan-hutan setempat.

18. Septi Peni Wulandari, seorang ibu rumah tangga yang sejak tahun 2008 mencetuskan dan menggerakkan Institut Ibu Profesional, yang dibentuk untuk menjadi laboratorium pencetak para ibu sebagai pilar keluarga yang tangguh, yang bersungguh-sungguh menjalankan peran sebagai ibu, sebagai perempuan, dan sebagai istri, yang ditempa secara kuat baik di ranah domestik keluarga maupun di ranah kegiatan publik. Beberapa tahapan untuk mewujudkan ibu profesional, antara lain tahapan Bunda Sayang, Bunda Cekatan, Bunda Produktif, dan Bunda Solehah. Untuk itu, Institut Ibu Profesional menggerakkan para ibu tangguh bermental pembelajar yang diharapkan akan mampu mencetak generasi penerus yang lebih berkualitas.

\section{SIMPULAN DAN SARAN}

Secara umum tipologi gerakan kewirausahaan sosial yang berkembang di dunia ternyata berbagai macam ragamnya, mulai yang berawal dari kiprah tindak nyata kepedulian sosial kemanusiaan merawat para 
korban perang hingga mempelopori pendirian sekolah perawat, dari yang menyumbangkan bagian besar keuntungan usahanya untuk meningkatkan taraf kesejahteraan hidup karyawannya, dari yang peduli pada pendidikan anak-anak hingga mengembangkan metode pendidikan anak, dari yang peduli pada kelestarian lingkungan alam hingga mempelopori pendirian lembaga perlindungan konservasi kebun binatang, dari yang menaruh kepedulian pada kehidupan masyarakat kelas bawah hingga menyediakan kredit mikro kepada mereka, dan masih banyak yang lainnya.

Gerakan kewirausahaan sosial di Indonesia, meskipun secara umum sama-sama bertujuan untuk membantu meningkatkan "kenyamanan" hidup masyarakat setempat, namun ternyata bentuk kegiatannya juga dapat bermacam ragam, tergantung dari ketersediaan daya dukung unggulan yang ada pada masyarakat setempat. Gerakan kewirausahaan sosial di Indonesia ada yang bergerak melalui bidang pemberdayaan ekonomi, melalui bidang kesejahteraan keluarga, melalui bidang pendidikan formal anak-anak, melalui bidang pendidikan non formal, melalui bidang kesehatan, melalui bidang kelestarian lingkungan alam, melalui bidang kebersihan/kesehatan lingkungan, dan masih banyak jalur bidang garap yang lainnya.

Berdasarkan uraian di atas, sebagai saran pengembangannya, selanjutnya perlu dikaji mengenai gambaran (pemetaan) tipologi gerakan kewirausahaan sosial terkait fenomena jejak sukses gerakan kewirausahaan sosial secara lebih mendalam lagi, yang juga mencakup informasi mengenai faktor-faktor apa saja yang mendorong munculnya semangat kewirausahaan sosial di tengah masyarakat, faktor-faktor apa saja yang memicu semangat pantang menyerah dalam menuntaskan penanggulangan permasalahan masyarakat, serta informasi-informasi berguna dan inspiratif lainnya.

Informasi yang diperoleh dari kajian secara mendalam tersebut diharapkan dapat dijadikan sebagai formula "virus" positif, yang dapat ditularkan dan diimplementasikan pada daerah-daerah lain, guna membantu menanggulangi adanya permasalahan yang terjadi di tengah masyarakatnya.

\section{DAFTAR REFERENSI}

Ashoka Indonesia, Apa Itu Wirausaha Sosial?, http://sea-dd.com/apa-itu-wirausaha-sosial/

Bariyanto, Social Entrepreneurship, kompasiana.com, 26 Juni 2015, https://www.kompasiana.com/bariyanto/social-entrepreneurship_5500ad74a33311ef6f511d27

Blog Indo Trading, Kewirausahaan Sosial (Kini) Jadi Perhatian Pemerintah, http://binaswadaya.org/bs3/kewirausahaan-sosial-kini-jadi-perhatian-pemerintah/

British Council, Keterampilan untuk Wirausahawan Sosial, https://www.britishcouncil.id/program/kemasyarakatan/kewirausahaan-sosial

CNN Indonesia, Melalui Nalacity Mantan Penderita Kusta Kembali Bersemangat, https://www.cnnindonesia.com/.../melalui-nalacity-mantan-penderita-kusta-kembali-b...

Deden Suparman, Kewirausahaan Sosial Berbasis Organisasi Masyarakat : Studi Analisis Pemberdayaan Ekonomi Ummat atas Unit Usaha Sosial Persis, NU, dan Muhammadiyah di Kabupaten Garut, Jurnal UIN Sunan Gunung Jati, Bandung, http://www.journal.uinsgd.ac.id/index.php/istek/article/viewFile/299/313

Elkington John, Pamela Hartigan, The Power of Unreasonable People : How Social Entrepreneurs Create Markets that Changes The World, Harvard Business Press, 2008.

Iin Febri Kurniati, Apa Itu Social Entrepreneurship?, https://iinfebrikurniyati.wordpress.com/2012/09/27/apa-itu-social-entrepreneurship/

Jawa Pos, Septi Peni Wulandari Penggerak Institut Ibu Profesional, https://www.jawapos.com/.../septi-peniwulandani-penggerak-institut-ibu-profesional

Karen Braun, Social Entrepreneurship : Perspectives on an Academic Discipline, Theory in Action, Vol. 2, No. 2, April 2009.

Luthfi Destianto, Kewirausahaan Sosial : Solusi Kemiskinan di Indonesia, kompasiana.com, 24 Juni 2015, https://www.kompasiana.com/luthfidestianto/kewirausahaan-sosial-solusi-kemiskinan-diindonesia_552a44fd6ea8340f70552cfc

Mestika zed, Metode Penelitian Kepustakaan, Penerbit Yayasan Obor Indonesia, Jakarta, 2008 
M. Nazir, Metode Penelitian, Penerbit Ghalia Indonesia, Jakarta, Cetakan Kelima, 2003

Monaliasakwati, Pengertian Social Entrepreneur (Wirausaha Sosial), http://monaliasakwati.blogspot.co.id/2011/12/pengertian-social-entrepreneur.html

Nur Rahman Arif, Social Entrepreneurship, wordpress.com, 24 Februari 2009, https://nurrahmanarif.wordpress.com/2009/02/24/social-entrepreneurship/

Sakina Rakhma Diah Setiawan, Luasnya Indonesia Jadi Tantangan Kewirausahaan Sosial, kompas.com, 29 September 2017, http://ekonomi.kompas.com/read/2017/09/29/123000326/luasnya-indonesia-jaditantangan-kewirausahaan-sosial

Social Station Project, Mari Kita Perdalam Pemahaman Kita Terhadap Kewirausahaan Sosial, https://socialstationproject.wordpress.com/category/kewirausahaan-sosial/

Vasudha Vasakaria, A Study on Social Entrepreneurship and the Characteristics of Social Entrepreneur, The Icfaian Journal of Management Research, Vol. VII, No. 4, 2008.

Wahyudi, Isa dan Busyra Azheri, Corporate Social Responsibility: Prinsip, Pengaturan dan Impelementasi, Penerbit Setara Press, Jakarta, 2011.

Website Rumah Zakat, https://www.rumahzakat.org/

Wikipedia Bahasa Indonesia, Bank Sampah, https://id.wikipedia.org/wiki/Bank_sampah

Wikipedia Bahasa Indonesia, Dompet Dhuafa Republika, https://id.wikipedia.org/wiki/Dompet_Dhuafa_Republika

Wikipedia Bahasa Indonesia, Kewirausahaan Sosial, https://id.wikipedia.org/wiki/Kewirausahaan_sosial

Wulan Melody, Pengertian Rumah Singgah, https://brainly.co.id/tugas/2129292

http://padadang.blogspot.co.id/2016/10/banyak-tokoh-social-entrepreneur-dunia.html

https://www.maxmanroe.com/inilah-5-social-enterpreneur-indonesia-peraih-danamon-social-enterpreneurawards-2015.html

http://padadang.blogspot.co.id/2016/10/4-tokoh-social-entrepreneur-indonesia.html

http://www.ayopreneur.com/sosial-mancanegara/4-pengusaha-yang-layak-menyandang-gelar-socialentrepreneur 